\title{
Natural Selection and The Cage
}

\author{
Ebrahim Salimikouchi \\ Department of Foreign Languages, University of Isfahan, Isfahan, Iran \\ Email: ebsalimi@fgn.ui.ac.ir \\ Camelia Talebian Sadehi \\ Department of Foreign Languages, University of Amin, Isfahan, Iran \\ Email: Cml_talebian@yahoo.com
}

\begin{abstract}
Naturalism flourished for the first time in France especially among Emile Zola and in his followers. Many European and American writers were influenced by this school and used its techniques in their writing. One of the main concerns of naturalists is the question of heredity and environment. Many naturalists focused on natural selection to analyze their society. This article intends to shed light on Sadeq Choobak's naturalism and the way he used natural selection in The Cage.
\end{abstract}

Index Terms - naturalism, Emile Zola, Sadeq Choobak, natural selection, The Cage

\section{INTRODUCTION}

Literary critics considered Sadeq Choobak as the true pioneer of naturalism in Persian literature. Emile Zola, for the first time, introduced naturalism in France and this school of thought originated from historical situation of the nineteenth century, the development of the science, industrialism, and Darwin's theories. Different events such as consumerism and dominance of industrialism led to class distinction and behavioral abnormalities. In the society, one could observe the rich men who had whatever they desired and on the other hand one could find the poor men who tried hard but gained nothing. Many social reforms, revolts and suppressed protests of the time were represented in literature by naturalists especially Emile Zola.

In addition to the development of science and industries, Darwin's theories had great effect on naturalism. Darwin believed that, based on natural selection, the strong members of species are able to live, and the weak ones are destined to die. In addition, he believed that the genes have great influence on individuals, the species and their variations. Assumptions based on these ideas might imply that, man does not have freedom to choose, but rather is under the influence of heredity and the environment.

Naturalists used repulsive subjects and themes and they focused on poor men's lives; moreover, their language was colloquial and they described every scene in detail (Afshar, 1996, p. 18). Unlike the classic writers, who paid attention to upper class people, naturalists focused on the workers, beggars, and neglected people. The same as scientists, the naturalists consider the dark aspects of poor people's lives without expressing their own feelings and thoughts. The naturalists believed that the writers should act like a camera, which shows all the repugnant and repulsive aspects of the society without any changes in them. That is the reason why the naturalists portray all the problems carefully and show the influence of the environment and heredity on people's destiny as pessimistically and cynically as possible (Ouliaei Nia, 2006, p. 18).

The classic writers focused on the beautiful life the upper class had and described all the portraits, architectural features, perfumes, and flowers which existed in their luxurious houses; however, the naturalists focus on the social and individual life of each man and woman and consider the bitter lives of those who are suppressed and ignored by society.

\section{SADEQ CHOOBAK}

Sadeq Choobak was born in 1916. In August 1941, Choobak, Sadeq Hedayat and some other writers introduced new genre, the short story, to Persian literature.

Choobak used colloquial and slang language in his works because he intended to reflect Iranian's character and style of life through their language. Besides, like American realist writers, he focused on the structure of the story.

When Choobak started his writing many writers paid great attention to social and political affairs of the society that is the reason why they focused on the poor people's situation and the injustice which dominated the whole society. Choobak represented the reality as objective as possible and as a naturalist focused on the cruel world in which people were trapped in the hand of destiny.

In his writing, Choobak, as one of the founders of modern Persian literature, attemted to go into details and give an exact image of the reality. 
Sadeq Choobak published his first book Puppet Show in 1945 and then he published his other books. He was considered as the writer of the first generation. "The writers of the first generation were those who used new techniques in their writing and made them fashionable in story writing" (Abdolahian, 2000, p. 23).

In contemporary Persian literature, critics considered Choobak as a naturalist because of his themes and techniques: Choobak used an objective point of view and reported the scenes in a similar way to a camera reflecting reality. In addition, his attention to the working class and poor people gave him the title of naturalist in Persian literature. Choobak's prose is "fluent and simple" (Kianoosh, 1974, p. 18) and his characters are selected from low classes of society. These characters almost speak colloquially and they do not have any freedom to choose, making them slaves in the hands of destiny. This kind of characterization in Choobak's plot is the representation of poverty, loneliness, corruption, injustice and inequality of people in the selected society.

\section{NATURAL SELECTION}

After returning from an exploratory voyage and studying Malthus's An Essay on The Principles of Population, Charles Darwin submitted his theories. His studies helped him to write his theories on natural selection. From 18421844, he developed and prepared the summary of his theories. Based on natural selection, defective, inefficient and inappropriate species are doomed to die and only strong species are able to live (Darwin, 1963, p. 168). Struggle for life between the weak and the strong species is one of the parts of Darwin's theory. In fact, natural selection appears to be the most important mechanism for creating complex adaptations in nature and the fittest species have the potentiality of survival, in another word, natural selection leads to the survival of the fittest.

If during the long course of ages and under varying conditions of life, organic beings vary at all in the several parts of their organisation, and I think this cannot be disputed; if there be, owing to the high geometrical powers of increase of each species, at some age, season, or year, a severe struggle for life, and this certainly cannot be disputed; then, considering the infinite complexity of the relations of all organic beings to each other and to their conditions of existence, causing an infinite diversity in structure, constitution, and habits, to be advantageous to them, I think it would be a most extraordinary fact if no variation ever had occurred useful to each being's own welfare, in the same way as so many variations have occurred useful to man. But, if variations useful to any organic being do occur, assuredly individuals thus characterised will have the best chance of being preserved in the struggle for life; and from the strong principle of inheritance they will tend to produce offspring similarly characterised. This principle of preservation, I have called, for the sake of brevity, Natural Selection. (Darwin, 1999, p.80)

\section{THE CAGE}

The Cage is the portrait of a hen-coop where many different hens and roosters live; there is not enough space in the cage and they peck each other and fight each other for food. This hen-coop is not only dirty but also too small; the birds have no freedom to move wherever they want; in addition, every other minute " a sun -scorched, veiny hand, filthy, ominous and calloused, thrust into the cage and searched among the caged ones (choobak, 1973, p. 64) then, the hand picks one chicken up. The other hens and roosters are indifferent to the victim's destiny and they still fight for food. Nothing changes in this cage; the story continues the same, all hopeless, unconscious, and waiting for their destiny.

Although the plot of the story seems to be simple, it has its own symbolic meaning which refers to the stupidity and ignorance of the people who live under the pressure (Hosseini, 2007, p. 151). Based on the plot, one can observe that Choobak, like all the other naturalists, paid great attention to the idea of natural selection and used it to add to the philosophical and ontological meaning of the text. Dehbashi believed that The Cage is the great portrait of "being or not being of man" and it is the same Naturalists' philosophical thought (Hosseini, 2007, p. 302).

A cage full of hens and roosters: neutered, scawny, scarred and snake-headed; cumin-colored, the color of bean flowers, the color of milk-rice, crested with featherless tails, short-legged; and misshapen, lame pullets, was placed on the edge of frozen jub. (choobak, 1973, p. 63)

One can consider the ice left outside the cage as the symbol of "dark and cold atmosphere dominated men's lives" (Mahmoodi, 2002, p. 97). The lives of theses hens and roosters which are entangled by the destiny and become alienated (Hosseini, 2007, p. 151) are the symbol of the social problems that never end and will last forever; there is no hope for its improvement.

Naturalists intended to get close to the language and techniques of scientists. As Flaubert mentioned, "the writer should efface himself and only report the realities, without engaging his emotions" (Haghighi, 1993, p. 122). Zola believed that

The novelist functioned like a scientist, observing nature and social data, rejecting supernatural and transhistorical explanations of the physical world, rejecting absolute standards of morality and free will, and depicting nature and human experience as a deterministic and mechanistic process. (Pizer, 1995, p. 47)

The same as some naturalists used many repugnant, repulsive and sometimes vulgar and obscene words and descriptions, The Cage has its own vulgar language and Choobak not only did not omit them but also emphasized them in order to reflect the pitiable situation of men. 
Near the jub next to the cage, rotten turnips, cigarette butts, cut off chicken heads and feet, and horse drug had fallen into the pit (choobak, 1973, p. 63)

Choobak as the true naturalist observed the outside world, described it, and reflected it in his story without giving any personal comments. This partial portrait of the reality helped Choobak to recreate the hidden, ugly and dirty aspects of life more precisely.

"The hideous and wicked aspects of the society are reflected through objects, scenes, and characterization in Choobak's works" (Hosseini, 2007, p. 241), in fact, the more the language is obscene and the description is more precise, the story is more persuasive; therefore, the reader can believe in natural selection more easily:

Those who had been beaten up their heads under their wings and legs, and beaks touched the shit on the floor whether or not they wanted to. Then, they were forced to touch the millet chaff stuck to in it. (Choobak, 1973, p. 64)

Outside, at the foot of the cage, an old-fashioned, sharp knife was cutting away at the chick's neck, and blood was spurting out. The hens and roosters could see this from inside the cage. (Choobak, 1973, p. 65)

In the above sentences, Choobak imitated the reality so precisely that the reader is able to imagine the scene in front of his/ her eyes. He selected the words carefully and reflected the extreme destitution and the unfortunate situation of these hens and roosters. By describing the fighting scenes between theses fowls and finding their food in the shit, Choobak presented the horrible situation of the selected society. In fact, "ignoring decorum is one of the aspects of naturalism and Choobak follows this rule" (Hosseini, 2007, p. 244).

In the selected society, the cruelty is so dominant and the situation in which the fowls live is so pitiable that none of them pays attention to the other fowls' destiny; they are doomed to die. As a result, The Cage is the story of the world, which is founded on the struggle for life (Dehbashi, 2001, p. 424).

In The Cage, natural selection is dominant; the weak fowls perish and the hand, which comes into the cage and symbolically represents the hand of the destiny, kills the survivors. As a result, one can notice that in The Cage "life is the combination of pain, suffering and bitterness; moreover, death walks everywhere" and the strong fowls rule over the weak fowls; the weak fowls naturally should be killed by the strong ones (Abdolahian, 2000, p. 57).

Presently, a red and flashy rooster made a furrow through the shit with its beak, picked it up and smeared it on the erect crest of a cumin-colored, shortv-legged hen. (Choobak, 1973, p. 65)

The fowls "are the victims and are condemned to coldness, loneliness, isolation, waiting and perplexity" (Dehbashi, 2001, p. 49). This suppressed fowls should struggle for their life and there is no way to escape this cruel destiny. They are blind, deaf and impotent not only in front of the destiny but also in the hand which comes into the cage each moment and lead them to die.

\section{CONCLUSION}

There are some tracts of the usage of elements and narrative techniques of naturalism in contemporary Iranian literature. This tendency is more characteristic and typical in Sadeq Choobak's work, which is named the representative and pioneer of naturalism in Iran. The detailed description, the use of colloquial language, his attention to low class people, insistence on representing the corruption of the society, ... are features of naturalism presented in his writing.

In his short story "the cage", Choobak portrays a defeatist and dark situation that emphasizes continually inadequacy, failure, and inconsistency. The deviant "they" in "the Cage" equals a "they" in distress, emptied of its substance. Its failures and its successive perturbations indicate the disruption and instability of the subjectivity in enunciation that is among the main characteristics of naturalism.

Although Choobak represented problems of the society hopelessly and pessimistically, he did not offer any suggestions for how to solve these problems. He not only described the hidden and hideous aspects of life but also developed his writing through different techniques. Is it possible for men to choose freely rather than to be slaves in the hands of destiny? It seems that Choobak like the other naturalists believed in men's condemnation in this world. This article is one example to represent how Choobak was influenced by "Darwin's natural selection" and the way Darwin believed in the effect of heredity and environment on men's situation. This cruel destiny considers men as his puppets and leads them to die.

\section{NOTES}

\section{The Cage}

Translated from the Persian by Charlotte Albright and Bahram Meghdadi

A cage full of hens and roosters: neutered, scrawny, scarred and snake-headed; cumin-colored, the color of bean flowers, the color of milk-rice, crested with featherless tails, short-legged; and misshapen, lame pullets, was placed on the edge of frozen jub. In the jub the dregs of tea, coagulated blood, the skins of sucked and squashed pomegranates, orange peels, dried leaves and other kinds of crap were all mixed together in the frozen ice. Near the jub next to the cage, rotten turnips, cigarette butts, cut off chicken heads and feet, and horse drug had fallen into the pit.

The floor of the cage was wet, carpeted with chicken shit. Dust and straw and millet chaff were mixed with the shit. The legs and feathers of the chickens and roosters were wet. They were wet with chicken shit. They were cramped, all of them huddled together and stuck together like kernels of corn on the cob. There wasn't even room to crouch, stand or 
sleep. They kept pecking each other's crests. There was no room. All of them were abused. None of them had any room. They were all cold. They were all hungry. They were all strangers to each other. Stench had filled the air. All of them waited. They were all in the same condition, and none of them was any better off than the other.

Those who had been beaten up their heads under their wings and legs, and beaks touched the shit on the floor whether or not they wanted to. Then, they were forced to touch the millet chaff stuck in it. Those who couldn't even touch the shit on the floor of the cage were forced to pick at the bars and stare outside. But there was no way out. Even subsistence was not possible in this place. Neither their cartilage beaks, nor their talons, nor their angry clutching, nor their force and pressure, nor their abusing each other helped them escape. But it amused them. The world outside was strange and cruel to them. Neither staring and looking painfully, nor the beauty of their wings and feathers helped them.

They were huddled together and pecked at their own shit and they drank from a broken bowl next to the cage. After drinking, they held up their heads in thanks and looked at the false and mocking ceiling of the cage, and moved their soft, thin throats.

While they were napping; they all waited out and watched. They were puzzled and didn't know what to do. There was no salvation. No avenue of existence or escape was open to them. They couldn't escape that cesspool. They were all biding their time; victims of a mass condemnation to coldness, estrangement, loneliness, bewilderment, and waiting. Suddenly, the door of the cage opened and there was a commotion inside. a sun -scorched, veiny hand, filthy, ominous and calloused, thrust into the cage and searched among the caged ones. The hand, with heartlessness, anger, and indifference, began to plow around among them and started a commotion. The caged ones smelt that familiar deathladen smell. They shrank and they flapped their wings and hid under each other's wings. The hand moved around above them, and, like a powerful magnet, shook them, as if they were iron filings. The hand searched everywhere, and, from outside, a radar-like eye led it until eventually stuck to the end of the wing of one emaciated chick and picked it up.

But the hand and the chick struggling in it, cheeping and flapping its wings, were hovering over the heads of the other hens and roosters, and had scarcely left the cage when the other hens and roosters began to scratch and peck and abuse one another in that cesspool. Coldness, hunger, confusion, estrangement, and waiting dominated them. They were all strange, indifferent, unkind, staring at one another or scratching each other with their talons.

Outside, at the foot of the cage, an old-fashioned, sharp knife was cutting away at the chick's neck, and blood was spurting out. The hens and roosters could see this from inside the cage. They were clucking and pecking at the bars of the cage. But the bars of the cage were hard. The world outside was visible, but there was no way out. They were looking curiously, in a frightened, expectant, weak manner at the blood spurting out of their cage mate who had just been freed. But there was no solution. That's the way it was. They were all silent, and the dust of death had been sprinkled over their cage.

Presently, a red and flashy rooster made a furrow through the shit with its beak, picked it up and smeared it on the erect crest of a cumin-colored, short-legged hen. The hen squatted down at once, and the rooster immediately mounted it. The wretched hen lay in the shit, then stood up. It shook itself and puffed up its wings and feathers, then started to peck the ground, then, it molted. It stood for a while and started pecking all over again.

The clucking and crying of a hen was heard. It circled around itself and then hastily squatted in the middle of the cage and abruptly laid an egg with no shell and covered with coagulated blood into the cesspool of the cage. Immediately, the sunscorched, veiny, filthy hand, ominous and calloused, tore into the cage and grabbed it out of that stinkhole, and, in the same moment, outside the cage, the mouth opened like a grave and swallowed it. The caged ones, while waiting, were staring into space.

\section{ACKNOWLEDGMENT}

I (Camelia Talebian Sadehi) dedicate this article to my father and my mother for their constant love and endless support. I would like to thank the following people whose help made the completion of this article possible. I am deeply indebted to Dr. Helen Ouliaei Nia for her enlightening ideas. I would also like to express my deepest gratitude to Dr. Hossein Pirnajmuddin for his gracious advice. Moreover, I also express my gratitude to Kayvan Tahmasebian for his helpful suggestions. I have really benefited from his knowledge and encouragement. Moreover, I express my thanks to Dr. Pyeaam Abbasi for his unwavering belief in me. And special thanks to the professors of English department of University of Isfahan and University of Amin for providing an academic atmosphere. Moreover, I express my gratitude to Dr. Laurie Rush for her encouragement. She devoted her time on revision of this paper and here I express my gratitude. Besides, I would like to express my gratitude to Dr. Ebrahim Salimikouchi who has given great advice and suggestions.

\section{REFERENCES}

[1] Abdolahian, H. (2000). Repertoire of Contemporary Prose Fiction, Drama, Academic Prose, Translation. Tehran: Papa Publication.

[2] Afshar, H. (1996). Naturalism. Tehran: Markaz Publication.

[3] Albright, Ch. And Bahram Meghdadi. Translation of The Cage. The Journal of Literary Translation. November 1980

[4] Choobak, S. (1973). Monkey Whose Master Had Died. Tehran: Javidan Publication.

[5] Darwin, Ch. (1963). The Origin of Species. Volume 49. London: Forgotten Books. 
[6] Darwin, Ch. (1999). The Origin of Species: By Means of Natural Selection- or the Preservation of Favoured Races in the Struggle for Life. United States: Bantam Classics

[7] Dastgheib, A. (1974). Apply Choobak's Works to Literary Criticism. Tehran: Kanoon Tahghighat Eghtesadi Va Ejtemaei Pazand Publication.

[8] Dehbashi, A. (2001). How True Choobak. Tehran: Sols Publication.

[9] Haghighi, M. (1993). Literary Schools. Tehran: Avang Noor Publication.

[10] Hosseini, F. (2007). Review of Choobak from Naturalist and Realist Perspective. Tehran: Tarfand Publication.

[11] Kianoosh, M. (1974). Review of Contemporary Persian Poetry and Prose. Tehran: Afsat Marvi Publication.

[12] King, G. Malthus, R. (1985). The Origins of English Social Realism. USA: Routledge, part of the Taylor \& Francis Group.

[13] Mahmoodi, H. (2002). Critical Analysis and Selection of Sadeq Choobak's Best Works. Tehran, Roozegar Publication.

[14] Ouliaei Nia, M. (2006). An Analytical Survey of American Literature. Tehran: Mirsaeid Farahani Publication.

[15] Pizer, D. (1995). American Realism and Naturalism. United Kingdom: Cambridge University Press.

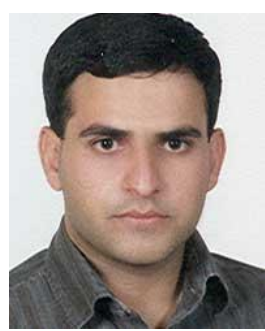

Ebrahim Salimikouchi is currently Assistant-professor of comparative and francophone literatures at the University of Isfahan and researcher at The National Center of Human Sciences. Besides teaching comparative literature and the sociology of literature, he writes short stories. His recent research publications and conferences include several articles on the works of Djebar, Sartre, Woolf, Emerson, Ben Jelloun, Dowlatabadi, Al-e Ahmad and Said. Some of his recent publications are: "Parcours de la francophonie en Iran : une francophonie latente" in Alternative Francophone, University of Alberta, vol.1, 4(2011): 99-112, Généalogie culturelle de nouvelle persane» (Tabarshenasi-e farhangui-e dastan-e koutah farsi), in La nouvelle persane, son expansion en Iran et au monde, Presses universitaires de l'université de Téhéran, « From Autofictional to the Social Reality. The case study: Fear and Trembling by Amélie Nothomb», in Plume, Special issue de colloque international de l'autofiction, 2011, "The conflict of doubt and belief in Kiss the Beautiful Face of God and Jean Barios (Comparative study)" in Comparative Language \& Literature Research, University of Tarbiat Modares, 2011, Literature of Migration», in The self and Others, Presses universitaires de l'Université de Téhéran, 2010, and Les infrastructures sociales dans L'enfant de l'autre de Jalal Al-e Ahmad», in Plume, $\mathrm{n}^{\circ}$ 9, 2010.

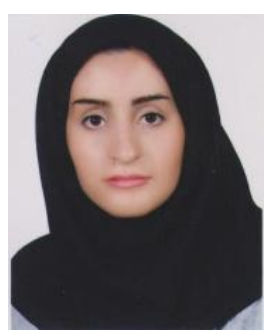

Camelia Talebian Sadehi was born in Ahwaz, Iran in 1987. She studied English literature and got her B.A. from University of Isfahan, Iran in 2009. Then, she continued the same major in M.A. and got her degree from University of Isfahan in 2011. She published two articles "The Melancholic Subject and The Bluest Eye" and "Beloved and Kristevan Melancholic Subject". She also attended some national and international conferences and presented her lectures. She is lecturer at University of Amin, Isfahan, Iran, and teaches English literature. 